\title{
Pedro A. González Moreno, Anaqueles sin dueño, Madrid, Hiperión, 2010, 88 pp.
}

Se echa de menos, en este nuevo libro de Pedro A. González Moreno, que no se especifique en la dedicatoria inicial quiénes son Pedro José y Enrique Moreno y por qué es pertinente dedicarles estos poemas. Creo que en este libro, además de una dedicatoria, es necesaria una advertencia para "espantar" a dos tipos de lectores de potencial igualmente nocivo: el "sensacionalista" y el "culturalista" que busque el dato erudito sin prestarse al esfuerzo de ahondar en la realidad humana que lo origina.

Revelando quiénes son los citados se revela de entrada que esta no es lírica libresca (que puede ser, por otra parte, tan digna como cualquier otra), que si el poeta ha elegido el tema del suicidio es porque se corresponde con su fondo vital más sangrante y hondamente sentido y le servirá, ante todo, para profundizar en viejas obsesiones que han ido tomando forma en libros anteriores (la muerte, el paso del tiempo, el arraigo en la afectividad que intenta salvarlos, y la poesía como posicionamiento ético y vital ante esa incertidumbre).

En cuanto al contenido de la obra, digamos primero lo más importante: Anaqueles sin dueño es un tratado sobre la piedad: lo que, si faltaran otros méritos, lo convertiría de entrada en un libro digno, sobre todo porque no se resigna a ser conciencia propia, delicadeza individual, sino que aspira a crecer en los otros y a crear en el lector una necesidad de empatía. Esta llamada ininterrumpida a la conmiseración es el eje del libro y la clave que nos permite interpretar la gran cantidad de prismas desde los que se afronta el hecho del suicidio.

Prismas como, por ejemplo, que el acto "luctuoso" reciba una intensa poetización que lo salva de su sordidez (la muerte de Goytisolo en El salto es casi éxtasis o rapto místico); que se apele a la comprensión del dolor íntimo del asesino de sí mismo; que el suicidio se justifique como un acto estético (De la turbia belleza), ético (destinado a salvaguardar la vida de su tránsito a la indignidad -como ya nos instruyó Séneca-, en El ruido de un sable o Sólo deriva), y hasta como un acto epistemológico que, en Orillas del Ouse, da una sugestiva vuelta de tuerca a un tema tan hecho lugar común como el suicidio de Virginia Woolf:

\footnotetext{
“¿Cómo será la última mirada desde dentro del agua? ¿Cómo el último brillo, ya sin color, de la materia, la levedad de un cuerpo que va hundiéndose..."
}

Prismas como el que eleva al suicida a la categoría de símbolo de la condición humana (Con nombre de erosión); o bien que (como sucede en Desde los terraplenes del insomnio y Calendario roto), se imponga cierta esperanza con la presentación de un mundo sensible hacia quien va a morir (los puentes de París sobrecogidos por la desaparición de Celan); o que se reivindique el auténtico (aunque frágil) amor a la vida de estos poetas, mostrando las últimas oportunidades que son capaces de concederle 
a la existencia antes de arrancársela; o que, finalmente, se presente el sucidio como un acto tan "fácil" que parece casi exigido por la propia inercia del vivir (Una llama en el agua).

Un poema excelente como Último amanecer, sobre Sylvia Plath, serviría como síntesis de todo lo anterior: la muerte en una mañana de sol como "antídoto" al tono lúgubre esperable, la directa implicación del autor, el último acto de amor inútil de dejar preparado el desayuno a los niños..., sencillamente impresionante. Las muescas de pura humanidad son tantas, y tan brillantemente defendidas, que la posible indolencia y cinismo del autor quedan sin cobijo posible y no tienen más remedio que firmar su rendición.

Junto a lo comentado, el lector atento y mínimamente versado en la poesía del autor encontrará múltiples guiños a su mundo creativo, ya sea a nivel de ideas (la manifestación de la decepción ante un oficio poético que es pura ortopedia de la vida que no se ha sabido reproducir, en Formas de la negación y La noche del visionario); o ya sea al nivel de simples imágenes (por ejemplo, en la descripción del interior de Costafreda como un caserón desolado - en Danza de fantasmas-; tampoco podía faltar un “desván (...) con su olor a baúles, con su danza de sombras/ y su lenta deriva/ de cosas muertas...).

En cuanto a técnicas compositivas, es necesario comentar estrategias tan hábiles como la creación de poemas a partir de versos suministrados por los autores que se retrata, con lo que se consigue, por lo menos, estas dos certeras dianas: en primer lugar, la generosidad de permitir a los poetas participar de su propio epitafio, y en segundo lugar dotar al libro de una densa atmósfera dramática de "continuación" de la obra poética que decidieron abortar, cuyas fisuras va completando el autor con un poso de tristeza impotente. $Y$, al igual que ocurre en los poemas de la breve breve plaquette del autor titulada Dodecaedro, son frecuentes los casos de "contagio", es decir, que la semblanza de un determinado poeta lleve implícita la asimilación de sus señas de identidad creativas: Así, en Instrucciones para no perderse dentro de un sueño, el versículo, los elementos irracionales y oníricos o la concepción del poeta como "visionario", se ajustan al retrato de un surrealista; o en La rosa nueva, los elementos de vanguardia lúdica, pero traspasada de compromiso social, se ajustan al de Maïakovsky.

Consignar finalmente que, una vez más, la estructura del libro vuelve a ser la más sabia: antes de la sucesión de baldas y autores malogrados, el Prólogo ha introducido el sobrecogimiento que aguarda al lector con la presentación de esa librería como un organismo "vivo" a costa del desgarro nunca salvable de quienes la pueblan. Los poemas Estantería y Anaqueles sin dueño, que alguien podría rechazar como simple reiteración de lo que va a exponerse, quedan justificados en la posición introductoria que ocupan (son anticipo, no repetición) y en la altura emocional de su imaginería:

“están todos

los que bebieron sed y nunca se saciaron, 


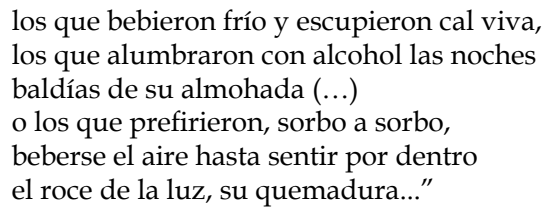

Y el Epílogo se hace depositario del hermanamiento emocional mostrado durante todo el libro con la decisión del poeta de enraizarse en esos muertos pese a la hipotética perturbación que aporten a su vida, gesto que, sencillamente, los reintegra de nuevo entre los aún vivos: "Al llegar cada tarde, cuando vuelvo del mundo,/ salen a recibirme con sus manos, aún tibias/ que nunca se acostumbran a morirse del todo; y a veces me preguntan/ cómo sigue la vida por la calle,/ si la avena está alta o si germina/ el último poema que dejaron escrito..."

Un último escalofrío para uno de los pocos libros auténticamente redondos (en contenido, forma y estructura) que nos ha regalado la última poesía española.

Rafael Escobar Sánchez 